\title{
Representações da masculinidade viril contemporânea no programa popular da Rádio Cidade FM: Hora dos Perdidos ${ }^{i}$
}

\author{
Representations of contemporary virile masculinity in popular Radio \\ Cidade FM program: Hora dos Perdidos
}

\section{Las representaciones de la masculinidad viril contemporánea, en el conocido programa de FM Radio Ciudad: Hora dos Perdidos}

\author{
Danielle Brasiliense | $\underline{\text { dabrasiliense@gmail.com }}$ \\ Universidade Federal Fluminense, Niterói, Rio de Janeiro, Brasil. \\ Pedro Ansel | anselpedro@gmail.com \\ Universidade Federal Fluminense, Niterói, Rio de Janeiro, Brasil.
}

\section{Resumo}

Este artigo busca analisar o exercício da virilidade masculina performatizada nos discursos midiáticos que circulam no cotidiano, pondo em evidência parte da dinâmica com a qual determinados valores constitutivos da cultura machista, forjados ainda na antiguidade, são atualizados pelas narrativas contemporâneas. O trabalho traz uma pesquisa sobre as narrativas midiáticas promovidas pelo programa Hora dos Perdidos da Rádio Cidade FM do Rio de Janeiro. Além disso, chama atenção também para as iniciativas de combate nas redes sociais da internet às abordagens sexistas que perpetuam a violência e a desigualdade de gênero naturalizadas em nossa sociedade. Com esta análise pretendemos perceber marcas do fluxo narrativo machista que se tornam banalizados nos discursos cotidianos.

Palavras-chave: masculinidade; rádio; performance; violência; identidade de gênero.

\footnotetext{
i Este artigo é resultado das reflexões feitas no grupo de estudos do Laboratório de Mídia e Violência, do grupo de pesquisa Subjetividades e Cultura da Violência, coordenado pela professora Danielle Brasiliense. O grupo de estudos está atualmente debruçado sobre a pesquisa "Cultura da virilidade: machismo midiatizado". Danielle Brasiliense é pós-doutora e professora adjunta do curso de Comunicação Social da Universidade Federal Fluminense e do Programa de Pós-Graduação em Cultura e Territorialidades. O coautor e mestrando Pedro Ansel é sociólogo e faz parte deste grupo de pesquisa. Ele está concluindo a dissertação sobre a temática das performances da masculinidade entre grupos de jovens que transitam pelas noitadas da zona oeste do Rio de Janeiro. O objeto desenvolvido neste artigo, o programa Hora dos Perdidos da rádio Cidade é apenas um dos muitos objetos analisados pelo grupo.
} 


\begin{abstract}
This article analyzes the exercise of performed male virility in media discourse circulating in daily life, putting in evidence of the dynamics with which certain fundamental values of machismo culture, forged since Antiquity, are updated by contemporary narratives. The paper presents a survey of the media narrative promoted by the program Hora dos Perdidos, in Radio Cidade FM from Rio de Janeiro. It also draws attention to the fighting in social media initiatives to the internet's sexist approaches that perpetuate violence and gender inequality naturalized in our society. With the analysis we intend to perceive the narrative flow marks become trivialized in everyday discourse.
\end{abstract}

Keywords: masculinity; radio; performance; violence; gender identity.

\title{
Resumen
}

En este artículo se pretende analizar el ejercicio de performatizada virilidad masculina en discurso de los medios que circulan en la vida diaria, la puesta en evidencia de la dinámica con la que ciertos valores fundamentales de la cultura del machismo, forjados, incluso en la antigüedad, se actualizan por las narrativas contemporáneas. El trabajo presenta un estudio de la narrativa medios promovida por el programa de radio de FM Tiempo Perdido ciudad de Río de Janeiro. También llama la atención a los combates en iniciativas de redes sociales a los enfoques sexistas de Internet que perpetúan la violencia y la desigualdad de género naturalizado en nuestra sociedad. Con este análisis se pretende realizar las marcas de flujo narrativo chauvinistas trivializado en el discurso cotidiano.

Palabras clave: masculinidad; radio; interpretación; violencia; identidad de género.

Contribuição dos autores:

Concepção e desenho do estudo - Em conjunto

Aquisição, análise ou interpretação dos dados - Em conjunto

Redação do manuscrito - Em conjunto

Revisão crítica do conteúdo intelectual - Em conjunto

Declaração de conflito de interesses: Nenhum

Fontes de financiamentos: Não houve

Considerações éticas: Nada a declarar

Agradecimento/Contribuições adicionais: Nada a declarar

Histórico do artigo: Submetido: 03.maio.2016 | Aceito: 21.jul.2016 | Publicado: 30.set.2016.

Apresentação anterior: Nenhuma

Licença CC BY-NC atribuição não comercial. Com essa licença é permitido acessar, baixar (download), copiar, imprimir, compartilhar, reutilizar e distribuir os artigos, desde que para uso não comercial e com a citação da fonte, conferindo os devidos créditos de autoria e menção à Reciis. Nesses casos, nenhuma permissão é necessária por parte dos autores ou dos editores. 
Cinco da tarde no Rio de Janeiro. Nas ondas do rádio FM, selecionamos a estação 102,9. A programação é da Rádio Cidadeii, no Rio de Janeiro, que lança um grito de guerra: “Alohaaaaaaa!!!”. De repente, a voz de um homem em forma de teaser diz: "se elas quiserem, elas vão ter". E segue uma música com trocadilhos sexuais masculinos: "Eu sou uma cobra venenosa que pica, que pica!/Eu tenho dois dentinhos afiados, que picam, que picam!”.

Todos os dias, o programa da rádio de rock popular carioca 'Hora dos perdidos’ tem uma hora de duração e vai ao ar ao vivo de segunda a sexta. O programa é voltado para o público adolescente e jovem, entre 15 e 30 anos, e já teve duração de duas horas durante a temporada de férias escolares entre os meses de dezembro e fevereiro. O ‘Hora dos Perdidos’ é apresentado por cinco locutores: Zeca, Paulinho Coruja, Pâmela Renha, Jean Presley e Pedro. Dentre eles também participa do programa uma jovem que habitualmente não tem o seu nome revelado e é denominada apenas como "a Estagiária Gostosa".

Todos os dias um tema diferente é debatido entre os locutores, que contam com a breve participação dos ouvintes para discuti-lo através de ligações para a rádio e suas redes sociais. As pautas são variadas, geralmente voltadas para o cotidiano, quase sempre oriundas de notícias recentes que circulam em veículos midiáticos. Por vezes, o programa também trata de datas comemorativas ou acontecimentos de interesse, como por exemplo o fim da revista Playboy ou o Dia Internacional da Mulher. Entre uma rodada de comentários e outra, os apresentadores tocam músicas do estilo rock, especialidades da Rádio Cidade.

A maior parte do programa chama atenção ao exercício de afirmação da identidade masculina, como pode ser facilmente identificado no discurso dos apresentadores. Todas as vezes em que os locutores dialogam entre si ou por telefone com os ouvintes, mais especificamente quando falam com as mulheres, a manifestação da performance da masculinidade é evidenciada. Não importando o assunto em questão, quando uma ouvinte entra no ar os diálogos seguem a mesma dinâmica: os locutores sentem-se à vontade para tecer afirmações e questionamentos sobre a vida sexual da ouvinte em tons de sarcasmo e descontração. O trecho retirado de um dos programas transcrito abaixo é representativo da condução destes diálogos:

Zeca: "Não temos a Estagiária Gostosa. Ela não pôde estar presente hoje, mas temos a C.C que com certeza é uma mulher linda, é uma mulher maravilhosa. Olha o sorriso dela de mulher bonita"

Zeca: Fala C.C, tudo bem, querida?

Ouvinte: Tudo.

Zeca: Você é uma pessoa que tem muita desenvoltura no telefone, já que este é o seu trabalho, não é verdade?

Ouvinte: É verdade!

Zeca: Então ouvinte, você que tem todo um jeito pra falar porque quem trabalha com o telefone tem um jeito diferente pra falar. Você já conquistou muitos corações, tem muito cara apaixonado por você?

Ouvinte: Não, só tenho um!

Pâmela: Ai que fofo!

Zeca: Tudo bem você só pode ter um que é a sua paixão, mas tem vários outros que são apaixonados por você! Ouvinte: Ah isso eu não sei.

Pedro: Ela não quer se comprometer.

Pâmela: Isso, é melhor nem saber!

Paulinho: Até porque o malandro deve estar do lado dela!

Ouvinte: Não tá do meu lado, mas está ouvindo.

Todos: Ah!

ii A Rádio Cidade foi fundada em 1977 e fez muito sucesso nos anos 80 e 90 no Rio de Janeiro. Foi a segunda rádio especializada em rock mais ouvida no estado, depois da rádio Fluminense FM, da cidade de Niterói. Interrompida em 2006 por alguns anos após a crise o Sistema de Rádio no estado, seguida da falência do Jornal do Brasil, a Rádio Cidade retornar em 2014 após campanhas via internet e redes sociais, nas quais fãs e cantores pediam sua volta. 
Paulinho: Se ele não tivesse ouvindo, ela entregava a lista de ocorrência.

Jean: Chifronésio!

Pâmela: Claro que não é.

Zeca: Ela tem uma voz extremamente gostosa.

Zeca: Qual é a música que você quer ouvir aqui na Cidade?

Ouvinte: ...

Zeca: Ela ainda tem o inglês gostoso!

Ouvinte: É porque eu trabalho em hotel, eu tenho que estar com o inglês em dia.

Zeca: Eu conheço pessoas fluentes.

Jean: Trabalha em hotel e é boa de línguas.

Todos: (muitos risos)

Com base não somente nesta, mas em outras participações das ouvintes nos programas acompanhados por nós, foi possível pontuar algumas características em comum do que seria a representação da masculinidade nos discursos dos locutores. Com exceção de Pâmela Renha, que não adota a mesma postura dos demais apresentadores, por vezes manifestando algum apoio às considerações das ouvintes, todos os locutores agem de forma muito espontânea e sem aparentemente demonstrar qualquer tipo de preocupação ou receio sobre como os comentários acerca das ouvintes serão por elas recebidos. Pâmela, embora possa ser vista como relativizadora, ocupa perto desses homens, de certa forma, o lugar da mulher representada pelo senso comum machista, ou seja, com voz pouco ativa. Isso não se dá apenas por ser a única mulher entre os outros quatro locutores, mas também por ter pouca autoridade para conter suas falas que envolvem normalmente questões sexuais ou estereótipos de misoginia disfarçados por um espírito brincalhão e simpático. Durante toda o programa, as mulheres são relacionadas a piadas de velhas posições de subserviência e fraqueza feminina.

Os discursos dos apresentadores possuem em comum a exaltação do corpo feminino em forma de assédio com afirmações do tipo: "Você é uma tremenda gostosa!", "Você é linda", "Tem voz de mulher gostosa", "Que delícia é você", "Toda mulher que faz curso técnico é gostosa", "Nós amamos você. É, nós mamamos você". Também são feitos questionamentos acerca da fidelidade da participante quando diz ter um relacionamento amoroso: "Não tem problema não, eu também sou casado, a gente peca junto!". Piadas de duplo sentido como intuito de suavizar o assédio verbal: "Trabalha em hotel e é boa de línguas", "E de linguiça você gosta?”, "Então quer dizer que você só dá se pedir, então me dá aí, pô!”.

Frente à exposição de diversas falas midiáticas sobre a questão do feminino notoriamente em alta nos últimos anos, consideramos importante pensar este lado da cultura da masculinidade para entender a permanência desses discursos, muitas vezes pré-conceitos que são fortemente reiterados em tempos de repressão ao machismo. Estamos em um momento de grande evidência do discurso sobre o corpo da mulher, sobre a questão do aborto, do assédio moral e sexual e tentativas de se reconstruir sentidos outrora relacionados ao gênero feminino. É por isso que nos sensibilizamos com a necessidade de pesquisar sobre o tema da masculinidade e suas performances, bem como também entender a noção de virilidade como herança discursiva do gênero masculino.

Percebemos que as noções de masculinidade e feminilidade são composições de gênero construídas discursivamente. Portanto consideramos importante mapear essas performances narrativas que atuam hoje no campo midiático e nos grupos sociais para entender seus teores, de que forma são construídos e em que momento. Para nós, os discursos sobre a virilidade um dia proferidos tanto na Grécia antiga ou no 
Renascimento, por exemplo, têm um papel importante de cristalização de valores - pensando em termos de dialogismo bakhtiniano $0^{\text {iii }}$ no universo discursivo que vivemos hoje.

O historiador Georges Vigarello, um dos organizadores da coletânea francesa "História da Virilidade”, discute na introdução do primeiro volume o termo grego "andréia". Este termo diz respeito às qualidades dos homens. São valores criados a partir da observação do comportamento dos guerreiros na antiga Grécia, cujo empenho, bravura e coragem, aliados à ideia de domínio sexual, os levava à condição da masculinidade perfeita. Do lado oposto estariam os covardes e perdedores.

Alguns ideais da "andréia" grega avançaram no tempo e atravessaram séculos, passando por diversas reformas de acordo com os interesses da sociedade em determinados momentos da História, com as mudanças culturais e as diversas formas de organização social. Suas características perdem, ainda na era dos sofistas, o foco na força física pela luta bruta, mas a importância do vigor e da dominação se mantém. O que chamamos hoje de 'macho' na forma popular se aproxima do significado da "andréia" grega, que aparece pela primeira vez no ano 467, segundo Maurice Sartre, no texto Virilidade Grega do livro História da Virilidade ${ }^{1}$ escrita na obra de Ésquilo:

[...] pois sua vontade (thymos) no coração de ferro, inflamada por sua andréia, pesava como aquela dos leões portando a guerra em seus olhos". Formada sobre aner, que designa o homem não como espécie humana (anthropos), mas como macho, a andréia possui um sentido menos sumário que a expressão homérica "ser humano". Obviamente, no coração, da noção encontra-se a coragem física, primeiramente aquela demonstrada em campo de batalha, mas que não é exatamente a demonstração da bravura e da força brutal do herói homérico..."

A educação do macho passa então pelo formato da "andréia", que também se mostra na capacidade de demonstração do desejo sexual e da força física através da exploração da beleza do corpo exibida por seus músculos. Era importante criar o homem capaz de seduzir outra pessoa, homens ou mulheres, a partir de sua beleza física. Isso aflorava o espírito de competição entre os homens, que precisavam expressar sua virilidade diante da população de sua cidade. A “andréia” está diretamente ligada à competição daqueles que eram fortes, bonitos, obedientes às leis e regras de civilidade; que suportavam o combate, não se cansavam e venciam. Suas qualidades estavam entre a educação, a moral e a beleza. A partir dessas regras se moldavam os lutadores guerreiros, maratonistas, atletas exaltados por sua coragem e obediência, o que definiu a educação viril. A virilidade sofista também levava em conta a capacidade de se expressar na construção da retórica oral. Saber fazer política também era uma demonstração importante para o homem macho.

Pós barbaridade medieval na história da masculinidade, esses ideais gregos vão ser reafirmados novamente no Renascimento, de acordo com a consolidação do Estado moderno centralizador das políticas públicas dos séculos XVI e XVII. Neste tempo a mudança está na proibição da vingança e da retaliação da honra à revelia dos cidadãos. É o rei, representante supremo do Estado, quem julgará a necessidade de combate. Novos tratados de civilidade são impostos e a vingança passa a ser algo não muito mais 'naturalmente' humano, e que por isso deve ser controlada. O conceito de virilidade é um pouco alterado na tentativa de ser algo menos brutal, mas nem por isso muito delicado: "a delicadeza, dito outroramente, não deve absolutamente comprometer qualquer rudeza viril"1. Assim nascem os machos moderados, que são bem parecidos com os que conhecemos hoje.

A cultura ideológica da masculinidade tem certamente uma forte herança nos ideais dos homens viris que viveram em séculos passados, especialmente aqueles que se empenharam no processo de civilização entre os séculos XVI e XVII, e que tentaram construir o sentido de viril a partir da ideia de força, potência e autoridade. Daí a importância desses discursos serem analisados: existem neles conceitos reafirmados na contemporaneidade, mesmo em contextos sociais completamente distintos.

iii O dialogismo, conceito aplicado pelo filósofo Mikhail Bakhtin nos garante a ideia da forte existência de uma herança da fala e dos significados de determinados sentidos construídos culturalmente através dos discursos e que podem ultrapassar o tempo sendo representados e reconstruídos a partir de um senso comum. 
Para isso é preciso saber: como se dá a construção e afirmação da heterossexualidade? Que noções de performance masculina podemos usar para avaliar os discursos midiáticos neste artigo? O que prende o gênero masculino aos discursos machistas? Com base nestas questões faremos uma análise sobre as narrativas machistas banalizadas e naturalizadas que parecem perdurar nas performances masculinas, neste estudo representadas pelos locutores da Rádio Cidade FM, rádio popular que fala diretamente com a juventude hoje. Para isso, é preciso, num primeiro momento, dizer o que seriam essas performances e que relações elas têm com as narrativas analisadas.

\section{A performance da masculinidade}

À luz do conceito de performatividade cunhado pela filósofa feminista Judith Butler, podemos concluir que os radialistas do programa 'Hora dos Perdidos', da Rádio Cidade FM, não reproduzem meros comentários ou brincadeiras desinteressadas como pode parecer num primeiro momento. Segundo Butler, dizer não é apenas dizer, "dizer é fazer" ${ }^{2}$. Consequentemente, os discursos que aparecem no âmbito do programa não são colocações descontextualizadas, mas sim discursos performativos que, ao serem construídos contribuem ativamente para o processo de construção da identidade de gênero. Para Butler, o gênero é uma 'contínua estilização do corpo', processando-se em uma repetição de atos que se cristalizam até que se torne natural. O gênero, portanto, é uma construção discursiva:

Tornar-se um sujeito feminino ou masculino não é uma coisa que aconteça num só golpe, de uma vez por todas, mas que implica uma construção que, efetivamente nunca se completa. Gênero não é algo que somos, mas algo que fazemos. Não é algo que se "deduz" de um corpo. Não é natural. Em vez disso é a própria nomeação de um corpo, sua designação como macho ou fêmea, como masculino ou feminino que "faz" esse corpo. O gênero é feito de discursos. O gênero é performativo².

O que Butler evidencia com o conceito de performatividade é que o gênero não é natural. Ele é fruto de uma construção social possibilitada e reforçada em diferentes âmbitos da vida através do discurso. As brincadeiras proferidas pelos locutores do programa 'Hora dos Perdidos', que ocorrem naturalmente sob forma de sarcasmo e bom humor, só se tornam possíveis pela dinâmica clássica da construção das identidades de gênero. Através da prática discursiva, os apresentadores reforçam uma divisão de gêneros pré-estabelecida, atualizando o papel clássico do masculino que usa a autoridade estabelecida num vínculo locutor/ouvinte mulher para assediá-las, exaltar partes de seus corpos e questionar suas vidas sexuais à revelia, mesmo sem, aparentemente, qualquer consentimento prévio. As respostas vêm em forma de risos passivos, que podem ser interpretados como sinal de constrangimento ou aceitação/'naturalização' daquilo que ouvem por se reconhecerem no discurso machista. Outros diálogos retirados do programa nos dão a oportunidade de acompanhar melhor este processo:

\section{Diálogo 1}

Pâmela: J, você tem quantos anos?

J: To fazendo 28 anos hoje.

Zeca: Parabéns J. Linda, tremenda gostosa, estou doido pra comer o seu bolo.

Paulinho: Fazendo 28 anos ele (o marido) vai te dar um presente que foi o que Maria ganhou atrás da horta!

\section{Diálogo 2}

Zeca: Você quer mandar um beijo para quem?

Ouvinte: Pra vocês todos e pra minha família que me atura porque eu sou chata pra caramba.

Zeca: Não, você não é chata não, você é uma tremenda gostosa, eu sei que é! 


\section{Diálogo 3}

Locutor: Então você estuda pedagogia. Eu não conheço ninguém que estude pedagogia que seja ruim. É tudo gostosa.

\section{Diálogo 4}

Paulinho: Seu sobrenome é Ventura, e eu queria ter uma aventura com você!

Ouvinte: Eu sou casada, rapaz.

Paulinho: Não tem problema, não, eu também sou, a gente peca junto!

\section{Diálogo 5}

Ouvinte: $\mathrm{O}$ homem não dá muito valor pra nós.

Zeca: Não, que isso, não fala uma coisa dessas!

Paulinho: Não, não, espera aí. Se a pessoa com quem a senhora tem um relacionamento um tanto quanto mais íntimo não dá atenção pra senhora, vem aqui que a gente dá.

Por meio desses discursos performativos, os radialistas do programa 'Hora dos Perdidos' reiteram não só as próprias masculinidades, como promovem também o reforço de signos machistas às identidades dos ouvintes. As ouvintes lidam com essas colocações de forma natural, riem e parecem achar interessante as falas que as exaltam sexualmente. Por conseguinte, cada uma delas, intoxicadas pelo seu próprio machismo contribui para que esse discurso seja cada vez mais naturalizado, recolocando a mulher em um espaço reservado apenas às suas qualificações sexuais, como se não houvesse nenhum problema em referenciar as mulheres sob forma misógina, com valorização apenas das suas atividades sexuais. As mulheres aceitam essa condição ao aceitarem abertamente a denominação de "gostosa”, restritiva em seu contexto. Já os homens demonstram se sentir ativos, poderosos, como se fossem caçadores mirando e encurralando uma presa. A divisão dos gêneros não escapa às significações do machismo; ela está presente tanto no discurso passivo das mulheres quanto no ativo masculino. Excluindo certos casos, homens ou mulheres parecem, neste programa, se identificar com os valores mais tradicionais da divisão de gênero heteronormativa historicamente estruturada.

Michael Foucault5, ao problematizar a conduta sexual na Grécia antiga em "A história da sexualidade I", discorre sobre um alicerce central na história da construção social que afeta as identidades tanto masculinas quanto as femininas até os dias atuais: a divisão binária entre 'ativo’ e 'passivo'.

O princípio de isomorfismo entre relação sexual e relação social. Deve-se entender por esse princípio que a relação sexual- sempre pensada a partir do ato modelo da penetração e de uma polaridade que opõe atividade e passividade- é percebida como do mesmo tipo de relação entre superior e inferior, aquele que domina e aquele que é dominado, o que submete e o que é submetido, o que vence e o que é vencido. As práticas de prazer são refletidas através das mesmas categorias que o campo das rivalidades e hierarquias sociais: analogias na estrutura agonística nas oposições e diferenciações, nos valores atribuídos aos respectivos papeis dos parceiros. E pode-se compreender, a partir daí, que há, no comportamento sexual, um papel que é intrinsecamente honroso e que é valorizado de pleno direito: é o que consiste em ser ativo, em dominar, em penetrar e em exercer, assim, a sua superioridade ${ }^{5}$.

O que Foucault nos traz ao expor o princípio de isomorfismo entre relação sexual e relação social é que esta divisão, moldada a partir do ato da penetração entre ativo (sujeito de prazer) e passivo (objeto de prazer), norteava as relações nas demais esferas da vida social. Estas duas categorias seriam entendidas naquele contexto como categorias a priori, ou seja, inerentes a uma natureza humana inata. Esta divisão estabelece que os homens, a exemplo da prática sexual, são naturalmente portadores da atividade (relacionada à dominação), e por isso têm a prerrogativa do domínio de funções sociais as quais mulheres seriam incapazes 
de exercer por conta da sua característica biológica passiva (atribuída a sujeição). "Quando, no jogo das relações de prazer, desempenha-se o papel de dominado, não se poderia ocupar de maneira válida o lugar do dominante no jogo da atividade cívica e política" ${ }^{5}$.

A divisão entre ativo e passivo, base do conceito que organizava a divisão de gênero na Grécia antiga, ainda hoje continua fomentando as desigualdades de gênero mesmo em uma realidade histórica e social completamente distinta. A homossexualidade, como exemplo de relações entre ativo e passivo, não constituía um problema nem de ordem moral nem política, visto que não eram reprovadas as relações entre dois homens na sociedade grega. As leis e conveniências citadas por Foucault dizem respeito à legitimidade das identidades e relações heterossexuais que dependiam inteiramente da não aceitação em assumir-se como objeto (passivo) nas suas relações. O fato de se relacionar sexualmente com um indivíduo do sexo masculino não promove por si só nenhum questionamento quanto à coerência da identidade masculina heterossexual neste contexto histórico; o problema está em identificar-se com o papel passivo que o sujeita à dominação.

O rompimento com a homossexualidade na composição da identidade heterossexual pela regulação e controle das formas como a sexualidade era vivida foi promovido por diversas instituições, como a família e a igreja. A deslegitimação desta forma de viver a sexualidade gerou ainda mais distinções no campo das identidades de gênero, pois homo e heterossexualidade passaram a ser inconciliáveis. A atribuição da passividade à identidade masculina, porém, continuou a ser igualmente repudiada na construção da masculinidade heteronormativa. Segundo Butler, tanto o gênero masculino quanto o feminino são culturalmente estabelecidos:

Através de proibições que impõem a perda de determinadas formas de viver a sexualidade e que reprimem o luto por essa perda. O objeto perdido no campo da identidade de gênero é a homossexualidade, mas essa perda permanece latente e internalizada. É uma "perda constitutiva" da identidade de gênero, da qual depende a coerência e estabilidade das identidades heterossexuais² ${ }^{2}$

Se a heterossexualidade é reconhecida como uma condição que deve ser constantemente perseguida, uma vez que não é um dado ou determinação natural (biológica) mas sim uma produção, sente-se agora a necessidade de alcançá-la plenamente, de repudiar veementemente a homossexualidade. É preciso que a homossexualidade seja concebida como algo abjeto, uma prática socialmente inconcebível. A regulação da identidade de gênero exige que a homossexualidade seja combatida e sufocada. É essa aversão que permite a constituição de identidades de gênero livres de questionamentos e ambiguidades, e é também este ideal que provoca a brutal afirmação da atividade masculina em seu extremo machismo.

Produzir identidades masculinas heterossexuais através da performatividade depende da participação ativa dos homens em se posicionar discursivamente contra qualquer traço de passividade (também sinônimo de feminilidade e homossexualidade) a que lhes possa ser atribuído. A ocorrência deste combate à homossexualidade pode ser captada na análise dos discursos do programa a 'Hora dos Perdidos' devido a constante exposição das preferências e desejos heterossexuais nas falas dos radialistas. Os comentários assediosos e provocações de cunho sexual dirigidos ao público feminino sugerem a tentativa de afastamento de qualquer questionamento sobre suas masculinidades. Ao demonstrar seu desejo pelo sexo feminino (passivo), eles reiteram a coerência de suas identidades masculinas.

O pavor de ser associado ao feminino, segundo Butler, advém do temor de perder a significância da idadentidade de gênero. A partir dessa perda, a identidade masculina passa a ser atribuída à homossexualidade e faz com que o homem seja ligado à identidade feminina, passiva e frágil; sua identidade torna-se então "monstruosa", instável. O processo de constituição da identidade masculina implica em "repudiar a feminilidade, pois esta é a prova de sua heterossexualidade. O desejo pelo feminino, diz Buttler, é também marcado pelo repudio a feminilidade. Ser um homem é desejar ter uma mulher, mas não ser uma mulher”2.

Alguns trechos do programa que foi ao ar em 08 de março de 2016, durante as comemorações do Dia Internacional da Mulher, paradoxalmente trazem não só a identificação repudiada que compõe a 
masculinidade heteronormativa, como também a visibilidade a outros pontos abordados neste artigo. Alguns trechos da transmissão em questão são destacados a seguir:

Zeca: Bom, senhores, hoje a Hora dos perdidos não é comigo. Quem vai comandar a Hora dos perdidos hoje, como é o dia internacional da mulher - e inclusive gostaria de dar parabéns a todas as mulheres desse mundo - hoje o comando geral desta mesa será de Pâmela Renha.

Jean: Olha só, mas que bosta.

Pâmela: Bosta é você.

Pâmela: Boa tarde, gente. Que prazer hoje estar no comando, mas não sou só eu. Temos a Mulher com Voz de Cigarro (personagem feito por Jean Presley) e temos a Estagiária Gostosa também. Então, temos três representantes mulheres aqui. Gostaria de estar agradecendo por estar fazendo isso aqui. E o tema de hoje é: quais os pontos positivos e negativos de sermos mulheres?

Jean: O Zeca gosta tanto de mulher que ele queria ser uma, né?

Zeca: Não, não, de jeito nenhum.

Pâmela: Se você fosse mulher, Paulinho, por que você ia gostar de ser mulher e por que você não ia gostar de ser mulher?

Paulinho: Se eu fosse mulher eu ia ser lésbica de tanto que eu gosto de mulher.

Pâmela: Mas eu tô falando sério, tô falando de um negócio sério. Você nasceu mulher, e aí? Qual seria a melhor parte de ser mulher e a pior parte de ser mulher?

Paulinho: A melhor parte de ser mulher é dar à luz e amamentar, homem nunca vai saber o que é isso, nunca vai saber!

Zeca: Olha que lindo.

Pâmela: Que lindo.

Paulinho: E a pior parte é ter alguém dentro de mim.

Pâmela: Agora vamos falar com nossa ouvinte J. Qual a melhor parte de ser mulher, J.?

J: É a intuição feminina. A gente capta coisas que o homem não capta.

Zeca: Linda, tremenda gostosa.

Pâmela: E qual é a pior parte de ser mulher?

J: Viver em um mundo que é setenta, oitenta por cento, machista. Isso é muito ruim.

Estagiária Gostosa: É verdade.

Pâmela: Concordo com você.

Pedro: Mulheres, não se envolvam com machistas e sim com baixistas.

Zeca: Isso é coisa que botam na cabeça de vocês?

Pâmela: Não, não.

Pedro: Isso é ruim na sociedade atual, porque a gente sofre com isso, mas isso não é natural pra ninguém, isso tem que ser mudado, isso não pode ser assim dessa forma.

J: Isso aí.

Pâmela: Isso.

Pedro: Isso não é natural da mulher, isso tem que ser mudado. Na verdade isso é uma coisa da sociedade que infelizmente é assim, mas a gente vai mudar isso.

Pâmela: Obrigada, J.

Zeca: J., estamos esperando muito você aqui na rádio, para beijar sua testa, seu cabelo e todo o seu corpo.

Pâmela: Estou com M. na linha. M, quais os pontos positivos e os pontos negativos em ser mulher?

M: Ponto positivo, eu acredito que é suportar muita coisa rindo que o homem não aguenta nem chorando.

Todos: (palmas) 
Paulinho: Nisso você está coberta de razão.

Pâmela: Estagiária Gostosa, qual é a melhor parte de ser mulher e qual é a pior parte?

Estagiária Gostosa: É saber ser mulher, né? Porque a mulher consegue fazer várias coisas ao mesmo tempo, o homem não consegue, a gente consegue muitas coisas.

Zeca: É verdade.

Pedro: Isso eu concordo com ela, é o que eu também acho é a melhor parte de ser mulher. Porque a mulher tem menos neurônios do que os homens e ainda assim...

Estagiária: O quê? Como é?

Paulinho: É, é comprovado.

Zeca: É comprovado cientificamente.

Pedro: Mas ela consegue fazer mais coisas, significa que menos neurônios são mais eficientes do que os homens que têm mais.

Zeca: A mulher também é infinitamente mais tolerante à dor do que o homem, isso aí é comprovado também.

A identificação repudiada sintetizada na citação de Butler "ser homem é desejar ter uma mulher, e não ser uma mulher" é flagrante na transcrição apresentada. A manifestação do desejo pelo feminino aparece como de costume nas falas dos locutores, entretanto a maioria das menções que os associam à feminilidade é veementemente negada pelos mesmos. O reforço da dinâmica que norteou o processo da divisão de gênero na Antiguidade também pode ser identificado: o binarismo atividade (masculina) / passividade (feminina). As características femininas valorizadas pelos apresentadores de ambos os sexos durante os trechos dizem respeito aos tradicionais critérios da "natureza passiva feminina", citados por Foucault ${ }^{4}$. Tais características figuram na exaltação do corpo feminino, intuição, ou tolerância à dor e maternidade.

A única vez em que a mulher é ressaltada em termos de atitudes é quando diz-se que ela "consegue fazer várias 'coisas' ao mesmo tempo que o homem não consegue”. Mesmo assim não dizem o que seriam estas "coisas" e a Estagiária Gostosa se apresenta num discurso vazio que logo é preenchido pela grosseria machista ao dar a entender que as mulheres têm poucos neurônios e, assim, não seria possível a estagiária construir um argumento melhor. Outro aspecto posto em evidência é a negação da própria participação na construção das desigualdades de gênero, como por exemplo, o momento em que a ouvinte J. menciona a posição desfavorecida da mulher que vive em um mundo predominantemente machista. O radialista Pedro, então, afirma: "isto não é natural da mulher, isso tem que ser mudado. Na verdade isso é uma coisa da sociedade que infelizmente é assim, mas a gente vai mudar isso”. Ou seja, para ele o mundo machista não é natural da mulher.

\section{A agressividade da performance machista}

As performances da masculinidade não são apenas uma prática do programa da Rádio Cidade. Em geral, outras rádios populares também demonstram comportamentos machistas de jovens apresentadores, e não apenas no Brasil. Em novembro de 2015, a rádio Power 106FM, de Los Angeles, entrevistou a cantora estadunidense Ariana Grande, que deu uma lição nos apresentadores do programa \#liftoff, Justin Credible e Eric-DLux. Durante a entrevistaiv, perguntam à cantora qual seria sua última escolha em vida, sua maquiagem ou um telefone.

Ariana Grande: É isso que os homens acham que as mulheres sempre têm que escolher?

Eric: Sim, nenhuma outra pergunta.

iv Disponível em: https://www.youtube.com/watch?v=Q9Dp53q5INc. 
Justin: A pergunta era: você consegue ir mesmo em algum lugar sem seu celular?

A: $\operatorname{Sim}$ !

J: Quantas horas você consegue ficar sem?

A: Muitas horas. Quando estou numa mesa de jantar, gosto de estar presente e falando, fazendo contato visual.

E: Mulheres, aprendam, escutem!

A: Meninos, aprendam!

E: Você está vendo a gente mexer nos nossos telefones?

A: Homens e mulheres, nós todos temos que aprender.

J: Você viu a nova atualização dos emojis?

A: Lógico que vi, adorei.

J: Quais são seus favoritos?

A: Eu amei todos: visualização das nuvens, do leãozinho.

E: Ah! Essas coisas a gente nem percebeu. Gostamos mais do dedo do meio e tal.

A: A saudação do Spock também é legal. E adorei a garrafa de champagne fofa e os unicórnios são ótimos, obviamente.

E: Garotas, ai ai...

A: É, garotos.... Muitos garotos usam o unicórnio.

E: É... "garotos"...

A: Hey! Ele precisa de uma conscientização sobre igualdade aqui. Vamos lá!

E: Garotos e não homens.

A: Não, quem disse que emoji de unicórnio não é para homens?

J: É? Nunca usaria esse emoji.

A: Ok, eu mudei de ideia, não quero mais discutir com esses caras.

(...)

A: Eu tenho uma longa lista do que gostaria de mudar. Acho que uma espécie de julgamento no geral.

Do tipo intolerância, maldade, padrões sociais, misoginia, racismo, sexismo, essas coisas. Temos muito a fazer sobre isso. É nisso que nós temos que nos focar, temos um trabalho a fazer. E vamos começar por você (apontando para o Eric).

E: Eu?

A: Sim, fiquei muito chateada sobre o emoji de unicórnio.

Quando Ariana Grande fala sobre o que gostaria de mudar, todos os radialistas concordam e também parecem atentar para os problemas que precisam ser mudados em sociedade, mas não conseguem sair do senso comum, das ideologias homofóbicas e machistas. A fala da cantora pop Ariana Grande viralizou, percorreu o mundo e foi aplaudida por grupos que lutam pela diversidade de gêneros e contra a misoginia. Poucos meses depois desta entrevista, em abril de 2016, Ariana estava de volta à luta pública contra o machismo ao defender-se de um comentário no Facebook que a taxava de "puta" no clipe da faixa principal de seu novo álbum à época, Dangerous Woman. Ela respondeu: “Quando as pessoas vão parar de se ofender com as mulheres mostrando a pele, expressando sexualidade? Homens tiram suas camisas, expressam sua sexualidade no palco, nos clipes, no Instagram, onde quiserem, o tempo todo. O critério diferenciado é tão chato e exaustivo. Com todo respeito, acho que é hora de tirar sua cabeça da sua bunda. As mulheres podem amar seus corpos, também”v.

v Disponível em: http://jovempanfm.uol.com.br/musica/criticada-por-clipe-sensual-ariana-grande-reponde-hora-de-tirar-suacabeca-da-sua-bunda.html. 
Em um programa da 'Hora dos Perdidos'vi, os locutores discutem o problema da intolerância e da tolerância. Eles chamam um ouvinte chamado Fernando para participar:

Zeca: A gente tem muita falta de educação no nosso país, mas muita gente diz que é uma questão cultural. O que você acha?

Fernando: São as duas coisas. Está tudo misturado, tudo embolado.

Zeca: O que você já passou de falta de educação na rua que você acha uma coisa horrível e acontece com frequência, Fernando?

Fernando: Pessoas não respeitando filas, idosos não terem lugar para sentar, mulher grávida em pé. (...)

O diálogo com Fernando não passa disso, eles desligam cordialmente. Percebe-se que não chamam uma mulher para falar sobre essa temática para eles tão séria. E continuam então com a discussão dentro do estúdio:

Zeca: Você, Mulher com Voz de Cigarro! (personagem interpretada pelo locutor Jean) ${ }^{\text {vii }}$ O que você vê de falta de educação que mais te incomoda?

Mulher com Voz de Cigarro: Essa coisa de não respeitar o idoso. Eu também passo por isso, porque sou gorda e velha. E aí eu chego no ônibus e não tem lugar para sentar, às vezes ficam aqueles adolescentes fingindo que estão dormindo. Abrem os olhos para ver se eu tô olhando.

Zeca: Uma vez eu vi um cara que bateu no ombro do estudante que estava sentado no assento para idoso. O garotão ainda quis debater com o cara. O cara disse, ô garotão olha aqui o idoso, levanta para ele sentar. O garotão virou para o cara e disse: levanta você. O cara levantou e foi até o garotão e disse: não quem tem que sair é você. Olha onde está, no lugar reservado para o idoso.

Estagiária Gostosa: O pessoal finge que não está vendo o idoso ali em pé.

Paulinho: Acho que tem que começar a falar alto. Eu gosto disso, de começar a falar alto mesmo pra todo mundo ver. A melhor coisa é o constrangimento. Não precisa agredir, não precisa fazer nada. Só precisa deixar a pessoa constrangida, com vergonha na frente de todo mundo. Nada melhor do que você tomar um esporro na frente de todo mundo. Sabe assim? Ficar com aquela cara de bunda?

Zeca: A falta de educação melhoraria se todos fossem a favor do prejudicado. Se todo mundo fosse contra o cara que fez besteira. Ô meu irmão, você tá errado!

Paulinho: O grande problema é que ninguém se coloca no lugar daquele que está sendo agredido. Se todo mundo se colocasse no lugar da pessoa isso não acontecia.

Zeca: A Zuleica (personagem também interpretada por Jean) já foi agredida várias vezes ali na central.

Zuleica: É verdade, o pessoal não respeita.

Zeca: Mas você estava vendendo coxinha estragada.

Zuleica: Não tava nada.

Paulinho: Os homens te bateram?

Zuleica: Bateram, os "homi".

Paulinho: E você gostou?

Zuleica: Foi ótimo!

(todos riem)

vi Disponível em: https://www.youtube.com/watch?v=8x9gzvgJ0aM.

vii Jean é o locutor que se veste de mulher e interpreta alguns personagens femininos estigmatizados, como a Mulher mais velha com voz rouca deteriorada pelo cigarro e a Zuleica, uma prostituta. Dentre outros personagens ele também imita o Padre Quevedo, Silvio Santos, Locutor de Supermercado entre outros. 
A discussão, que parecia cara para os locutores e ouvintes, começa com uma pergunta para um homem, que é levado a sério e acaba com uma piada machista, num diálogo com uma personagem prostituta. Para eles, ela merecia apanhar por ter supostamente vendido um salgado estragado. A personagem garante a piada quando reforça o machismo dizendo que gostou de apanhar. Toda a discussão de tolerância perde seu valor, visto que para os locutores a violência contra a mulher parece não se encaixar no conceito de intolerância.

O Coletivo Mulheres em Movimento ${ }^{\text {viii }}$, no dia 19 de março de 2014, fez uma nota no Facebook sobre o programa "Hora dos Perdidos" da Rádio Cidade. Nesta nota, o coletivo denuncia as piadas e os comentários machistas enunciados na rádio:

\section{Nota para a Rádio Cidade (Programa Hora dos Perdidos)}

Como se não bastasse o preconceito que mulheres homossexuais - lésbicas e trans - sofrem diariamente, a Rádio Cidade voltou com um programa chamado Hora dos Perdidos, no qual são reproduzidas piadas ofensivas e comentários de mau gosto absolutamente desnecessários. São brincadeiras machistas, transfóbicas e homofóbicas que não podemos tolerar, pois perpetuam e enraízam ainda mais os preconceitos opressões numa sociedade que já está farta deles. Não podemos aceitar que quando ouvintes mulheres ligam façam-nas passar por diversos constrangimentos aos pedidos de sussurros e vozes sexy. Não podemos conceber que uma Rádio chegue ao cúmulo de comparar uma mulher a um pavão, fazendo alusão a um "rabo bonito". Devemos intervir. (...)

Em nome da luta contra o machismo e o patriarcado, contra todas as fobias às minorias em direitos, o Coletivo Mulheres em Movimento faz um pedido à Rádio Cidade: o roteiro dos programas, sobretudo a Hora dos Perdidos, PRECISA ser modificado.

Este post foi encontrado pelos autores deste artigo através de pesquisa no buscador Google com as palavras-chave "Hora dos Perdidos+machismo", e tem apenas 20 curtidas e dois compartilhamentos no Facebook. Não encontramos nenhuma resposta da Rádio para esta nota; entende-se, portanto, que foi ignorada, o que nos faz reconhecer que, de certa forma, os discursos de performance machistas são naturalizados pelos apresentadores do programa. Por esse motivo, criam-se campanhas como \# chegadefiufiu ou \#meuprimeiroassedio contra o assédio sexual, produzidas pelo coletivo feminista Think Olga ${ }^{\text {ix }}$, que usa as redes sociais para dar visibilidade e reconhecimento à necessidade de se estancar socialmente os fluxos intensos de machismo, desrespeito e violência contra a mulher.

A campanha \#chegadefiufiu começou em 2013 e teve como objetivo combater o assédio sexual em ambientes públicos, quando são configurados os olhares e toques indesejáveis e quaisquer tipos de falas com teor sexual direcionadas às mulheres. Nesse caso, a \#chegadefiufiu criou uma campanha direta contra narrativas como as feitas no programa da Rádio Cidade, pois a tentativa é de desconstruir o que se naturalizou como cultura da masculinidade. Aquilo que é entendido pela cultura machista como algo agradável e positivo (um flerte, por exemplo) é para esta campanha a fotografia do desrespeito à posição da mulher, vista nesta sociedade como agente passiva que se relaciona com uma autoridade marcada pelos ideais do patriarcado e da heterossexualidade ativa. Em um vídeo/palestra no Youtube ${ }^{\mathrm{x}}$ que ocorreu no TEDxSãoPaulo, Juliana Faria, a criadora do Think Olga e da campanha \#chegadefiufiu, conta que, no começo, sofreu alguns tipos de preconceitos por parte de alguns jornais que diziam ser uma "campanha de mulheres mimadas". Juliana cita uma das manchetes sobre sua campanha veiculada por um desses jornais: “Assédio sexual: violência contra mulher ou mimimi de rede social?”.

Segundo Juliana, esse tipo de matéria jornalística acabou dando força para comentários machistas nas redes. O coletivo Think Olga, a partir da campanha \#chegadefiufiu, fez uma pesquisa através da qual recolheu

viii Mulheres em Movimento é um coletivo feminista e anticapitalista que atua, principalmente, na região da Zona Oeste do Rio de Janeiro.

ix O Think Olga foi criado em abril de 2013. É um projeto feminista com objetivo de criar conteúdo de reflexão sobre a complexidade do tratamento dado a mulher. O objetivo é empoderar as mulheres para que elas tenham suas próprias escolhas em contrapartida ao machismo.

x Disponível em: https://www.youtube.com/watch?v=BpRyQ yFjy8. 
depoimentos de mulheres e obteve resultados que foram transformados em um mapa do assédio no Brasil. Entre pelo menos oito mil mulheres que responderam aos questionários distribuídos, $98 \%$ delas sofreram assédio e $83 \%$ não gostam de cantadas. Aqui estão exemplos de três depoimentos do site Think Olga ${ }^{\mathrm{x}}$ :

\section{Cibele P.}

Num ponto do caminho veio um "bando" de garotos sem que eu percebesse e bateram na minha bunda, passaram a mão em mim como se fossem cegos tateando algo e me ofenderam com palavras nojentas, muito nojentas. No primeiro momento me senti acuada e sem reação (talvez por que eram muitos), a não ser berrar que mataria eles e como eles foram filhos da puta!

\section{V.F.}

Quando eu tinha 10 anos estava numa feira de artesanato. Vestia calça jeans e um top laranja. A feira estava cheia e enquanto eu olhava alguns colares, um homem tentava abrir passagem por trás de mim, sem conseguir, já que levou uns 5 minutos para sair. Pelo menos foi isso que eu achava. Quando cheguei em casa e contei sobre isso levei bronca da minha mãe que me mandou tirar aquela roupa e tomar banho imediatamente. Comecei a chorar, pois finalmente havia entendido que o homem estava se esfregando em mim e não abrindo passagem.

\section{Laís S.}

Atualmente tenho 18 anos, mas, desde os 14 anos, um rapaz bem mais velho que mora na minha rua, somente algumas casas depois da minha, começou a soltar piadinhas sempre que eu passava por ele. Além do constrangimento provocado pelas piadas indecentes, estas eram gritadas no meio da rua, na frente de quaisquer pessoas que estivessem por perto, o que me constrangia mais ainda. Por causa de todo esse constrangimento, passei a ficar com medo de sair sozinha de casa, pois, na maioria das vezes, tinha que passar pelo sujeito e ser assediada publicamente. Assim, passei a utilizar um outro caminho para chegar em casa, muito mais longo do que o de costume, perdendo, assim, minha liberdade de locomoção. Hoje em dia ainda sinto medo quando passo por ele na rua, porém, não desvio mais o caminho e ele não diz mais nada quando passo - felizmente acho que se cansou de tanto ignorá-lo.

A violência é a expressão mais grave do machismo, mas são os discursos de reforço da heterossexualidade, como os do programa da Rádio Cidade, que alimentam esta violência cotidiana. Enquanto a Rádio Cidade colocava no ar o programa 'Hora dos Perdidos' no último 08 de março, Dia Internacional das Mulheres, como mostramos anteriormente, o jornal paulista O Estadão publicavana rede social Twitter, a cada 7 minutos das $24 \mathrm{~h}$ desse dia, denúncias de agressões contra a mulher que haviam chegado nos últimos 10 meses na Central de Atendimento à mulher (telefone 180). A ideia foi chamar a atenção do público para a violência contra a mulher e ajudar no empoderamento das mulheres que se sentem constrangidas e ameaçadas diante de atitudes masculinas.

\section{Twitter @Estadao:}

Denúncia 89 do dia: Homem golpeia esposa com facão no interior do Piaú. \#7minutos 1 denúncia. $5 \mathrm{~m}$

Denúncia 88 do dia: Na tentativa de fugir do marido, mulher se joga de carro em movimento. \#7minutos 1 denúncia. $12 \mathrm{~m}$

Denúncia 87 do dia: Em Arapiraca mulher apanha do próprio marido dentro de bar. \#7minutos 1 denúncia. $20 \mathrm{~m}$

Denúncia 86 do dia: Homem não se conforma com fim do casamento e baleia a ex-mulher. \#7minutos 1 denúncia. $26 m$

xi Disponível em: http://thinkolga.com/chega-de-fiu-fiu/depoimentos/. 
A violência é um ato de constrangimento com força infligida a alguém e a agressividade é uma potência dessa violência, que em nossa cultura é inibida pelos ideais de civilidade e ordem. Todavia, entre os discursos que formam a ordem social, existem crenças históricas sobre o valor da honra heterossexual que foge ao controle da masculinidade civilizada. Quando a heteronormatividade se encontra ameaçada e os ideais de gênero masculino acuados, muitos homens de alguma forma parecem lutar para não perder sua honra e usam a violência, há muitos séculos, como forma de garantia da sua força. Violência e agressividade tornam-se compensatórias para que não se perca a dignidade da virilidade e para fugir da vergonha.

O que se deve levar em conta ao prestar atenção nas performances masculinas e em seus resultados violentos é que esses discursos são construídos socialmente a partir da exaltação de um poder: a sexualidade dos jovens machos. Essa exaltação de poder compromete a valorização do gênero feminino, restringindo-oem sua forma de entendimento como elemento passivo. $\mathrm{O}$ homem viril que afirma seu poder heterossexual machista nega imediatamente qualquer tipo de sensibilidade que o coloque em um espaço que possa parecer feminino. Ele tem horror em demonstrar algum tipo de delicadeza.

Torna-se importante pensar na manutenção e exposição de discursos machistas que enaltecem a honra e a submissão da mulher. Esses discursos são mesmo interessantes para tais programas de rádio? O que a Rádio Cidade, como mediadora, ganha com a exaltação dessa ideologia? O que ela perde num momento de mudanças sociais e de questionamentos sobre o binarismo dos gêneros? Com uma nova geração tecnológica e de espírito libertário entre as idades de 18 e 35 anos, ainda vale reforçar tais discursos e performances machistas?

\section{Referências}

1. Corbin A, Courtine JJ, Vigarello G, Melo Sobrinho NC, Florêncio TAL. História da virilidade. Rio de Janeiro: Vozes, 2013. (A invenção da virilidade da antiguidade às luzes; vol. 1).

2. Butler J. Corpos que pesam: sobre os limites discursivos do sexo. In: Louro GL, Silva TT. O corpo educado: pedagogias da sexualidade. Belo Horizonte: Autêntica, 2000. p165.

3. Butler J. Feminismo, Sexualidade e Justiça no debate entre Judith Butler e Nancy Fraser: Cyfer, Ingrid. São Paulo: UNIFESP, 2011.

4. Foucault M. História da sexualidade I: a vontade de saber. Rio de Janeiro: Graal, 2012. (Biblioteca de Filosofia e História das Ciências).

5. Foucault M. História da sexualidade II: o uso dos prazeres. Rio de Janeiro: Graal, 2012. (Biblioteca de Filosofia e História das Ciências). 